\title{
An Analysis of Section 15 of the Juvenile Justice Act, 2015
}

\author{
Deepak Singh*
}

\begin{abstract}
The Juvenile Justice Act, 2000 was strongly criticized by scholars from all spectrums of the society for its perceived failure to hold the child offender accountable. Therefore, emphasis was laid on increasing the quantum of punishment, in order to act as an effective deterrent. In the backdrop of the Nirbhaya case, the Parliament of India rushed to enact the Juvenile Justice Act, 2015 as a fire-fighting measure, to mollify the public clamour. As per the new Act, children aged between sixteen to eighteen can be transferred to an adult criminal court, in the event they are alleged to have committed a heinous offence. The paper aims to analyze the framework of Section 15 of the Act, in the context of a juvenile's physiology. An attempt has also been made to study how other nations around the world are addressing the problem of juvenile delinquency. The paper concludes by highlighting the ambiguity in the legislation and suggests solutions for doing away with the same.
\end{abstract}

Keywords: Criminal recidivism, juvenile delinquency, Section 15 of the Juvenile Justice Act, 2015, social defense, United Nations Convention on the Rights of the Child, 1992

\section{Introduction}

At the outset, it is pertinent to clarify what the author means by Juvenile Justice system (hereinafter referred to as JJS) for the

\footnotetext{
*National Law University Odisha, India; 15ba066@nluo.ac.in
} 
purpose of the paper. The paper deals only with that aspect of juvenile justice which includes criminal conduct. The author excludes from consideration the other facets of the act, i.e. care, protection, adoption and neglect. The author has used the term juvenile, adolescent and children interchangeably as these terms do overlap. It is also germane to explain the nature of juvenile delinquency beforehand. Juveniles are generally accepted to be different from, and are treated differently, unlike adults, both in the legal and social contexts, on the basis of their age. ${ }^{1}$ In generic terms, juvenile delinquency has been defined as deviant child behavior. When a young person is involved in a criminal act, he is referred to as a juvenile delinquent, juvenile offender or a youthful offender, and the crime, as juvenile delinquency. ${ }^{2}$

The Juvenile Justice (Care and Protection of Children) Act 2015 (hereinafter JJ Act, 2015), as passed by Parliament, received the assent of the President of India, on December 13, 2015 and is applicable to the whole of India, except the state of Jammu and Kashmir. The gruesome rape in the Nirbhaya case, where one of the offenders was 17 years old, just 3 months short from attaining majority, fueled the concern that the Juvenile Justice Act, 2000 was ill-equipped to deal with this new breed of delinquents, the socalled juvenile superpredators. ${ }^{3}$ The policy elites, the media, as well as ordinary citizens, from all spectrums resorted to questioning the legitimacy of the juvenile legislation and the need for the adoption of stringent punishment, to act as a deterrent. The Parliament, under unprecedented scrutiny and criticism for its perceived inability to respond to the Juvenile menace, succumbed to the demand of some critics riding on the myth of superpredators. ${ }^{4}$ Thus, the Parliament brought in the JJ Act, 2015 to make it easier to prosecute juveniles as adults. Under the existing framework, a

1 Adolescent Development $\mathcal{E}$ Competency, NAT'L CONF. OF STATE LEG., http:/ / www.ncsl.org/documents/cj/jjguidebook-adolescent.pdf.

2 Sima Nieborg Et Al., VerWEy-JONKER INSTITUUt, CHILD AND JUVENILE

DELINQUENCY: STRATEGIES OF PREVENTION AND INTERVENTION IN GERMANY AND THE NETHERLANDS 20 (2000).

3 Addie C. Rolnick, Untangling The Web: Juvenile Justice In Indian Country, 19(49) N.Y.U JOUR. OF LEG. \& Pub. POlicy 49, 101-02 (2016). ${ }^{4} \mathrm{Id}$. 
child between the age of 16-18 years, alleged to have committed a heinous offence, may be transferred to an adult criminal court, known as children's court, to be tried as an adult. ${ }^{5}$ Section 15 of the JJ Act, 2015 is the most contentious provision, mandating the Juvenile Justice Board (hereinafter referred to as JJB) to transfer cases involving a child between 16-18 years, alleged to have committed a heinous offence, to a children's court. This decision is to be made by the Board on the basis of a preliminary assessment conducted to examine the child's capacity to commit such an offence. This Section casts an onerous obligation on the JJB to take the assistance of psycho-social workers, psychologists and other experts, in order to come to a conclusion regarding the mental capacity of the said accused. If the Board is satisfied in its preliminary assessment, then it may transfer the child to be dealt by the Children's Court, under Section 18(3). ${ }^{6}$ The author submits that the provision requiring preliminary assessment of the child is a subjective process, creating scope for enormous arbitrariness. The legislature has failed to take into account modern scientific evidences which unequivocally show that individual assessment of a child's mental capacity is not possible. Although the JJ Act, 2015, was passed after the implementation of several international legal instruments on children's rights, it does not align with the international mandates set. The transferring of a child into the adult criminal justice system, as envisaged by the JJ Act, 2015 is also in violation of Articles 14 and 15(3) of the Constitution of India.

The first half of this paper summarizes the historical context of Juvenile justice legislation in India. The next, reviews the international mandate set by the international legal instruments, which India fails to conform to. The author also analyses the framework of Section 15 and the plausibility of assessing a child's mental capacity vis-à-vis criminal culpability. The paper also examines the JJ Act, 2015 with respect to the fundamental rights of the Indian Constitution. The author has also carried out a comparative examination of the juvenile justice system prevalent worldwide, for a better understanding of this system. Reference has

${ }^{5}$ The Juvenile Justice (Care and Protection of Children) Act, No. 02 of 2016, INDIA CODE, §§ 15, 2(20) (2015) ${ }^{6} \mathrm{Id}$. 
been made particularly to Uganda, South Africa and France, known for enacting progressive laws in relation to juvenile delinquency. The author concludes by proposing solutions to remove the ambiguity inherent in the legislation.

\section{The History of Juvenile Delinquency}

Understanding the existing state of JJS in India requires recourse to history. The paradigm shift in the conception of children during the industrial revolution, led to the emergence of a separate juvenile justice system in the western countries. ${ }^{7}$ In India, the JJS originated during the British rule in India. The reform movements taking place in the United Kingdom influenced India heavily. However, the changes introduced in India, in order to deal with juvenile delinquency were not limited only to those measures adopted in the United Kingdom. ${ }^{8}$ The subsequent legislation in India, spearheaded the jurisprudence of criminal law and its procedural safeguards. The Indian courts took after the American juvenile courts in adopting a parens patriae model in relation to matters of youth delinquency. ${ }^{9}$ Juvenile courts assumed a paternalistic attitude pursuing the doctrine of parens patriae, emphasized supervision, treatment, and control towards juvenile delinquents. ${ }^{10}$ Consequently, the treatment of juvenile offenders was different in nature.11For some time, juvenile courts lent themselves to procedural informalities, owing to which the juveniles were not accorded the same procedural safeguards as their adult counterparts. ${ }^{12}$ This cavalier approach to the rights of the delinquents, led to due process concerns, and by the 1960s, a series of U.S Supreme Court decisions recognized due process

7 Barry C. Feld, Juvenile and Criminal Justice Systems' Responses to Youth Violence, Crime and Justice, 24 UNI. OF CHICAGO PRESS 189-261 (1998).

8 Ved Kumari, The Juvenile Justice System in India from Welfare to Rights, Oxford India Paperbacks, (2003).

9 Ex Parte Crouse, 4 Wharton 9 (Pa. 1839).

10 Julian William Mack, The Juvenile Court, 24 HARV. L. REV. 104 (1909).

11 A. Morris and H. Giller, Understanding Juvenile Justice, 8 Nat. Cri. Justice Reference Service (1987)

12 Howard W. Snyder \& Melissa Sickmund, National Ctr. for Juvenile Justice, Juvenile Offenders and Victims: National Report 88-89 (1999) 
rights in juvenile proceedings. For instance, the Supreme Court in In re Gault engrafted formal procedures onto juvenile courts. It observed that "the absence of substantive standards has not necessarily meant that children receive careful, compassionate, individualized treatment. Departures from established principles of due process have frequently resulted not in enlightened procedure, but in arbitrariness". ${ }^{13}$ Gradually, the 'welfare' approach (parens patriae) shifted to a 'rights' based approach, which complies with the Constitutional and procedural rights enshrined in the Constitution ${ }^{14}$

From early 20th century onwards, each state in India had its own Act, dealing with the issue of juvenile delinquency. The Madras Presidency, an administrative subdivision of British India, was the first to enact its juvenile legislation. Shortly afterwards, Bengal and Bombay in 1922 and 1924, enacted their respective legislations on children. These courts implemented benevolent and paternalistic policies under the welfarist mode. ${ }^{15}$ The Government of India legislated the Children Act in 1960, to provide for the trial of juvenile delinquents in the Union Territories, as a model to be followed by the states, in the enactment of their respective legislations concerning juveniles. As per the act, a child was defined as a boy under the age of 16 years of age, and a girl, below 18 years of age. 16 Every state had its own children act and procedures. The cut-off age provided in each Act lacked consistency in terms of definitions as well as in the procedures adopted therein. The definition of "child" differed from state to state. This prompted the Apex Court to emphasize on the need for a uniform Children act. In the case of Sheela Barse v. Union of India, ${ }^{17}$ the court observed:

13 In re Gault, 387, U.S. 1, 18 L. Ed 527 (1948); Haley v Ohio 332 US 596, 92 L. Ed 224 (1948).

14 Sesha Kethineni \& Tricia Klosky, The Impact of Juvenile Justice Reforms in India, 44 Int'1 Jour. of Offender Therapy and Comparative Crim. 312-25 (2000)

${ }^{15}$ Maharukh Adenwalla, Juvenile Justice Reforms in India, Childline India Foundations (2006).

16 The Children Act, 1960, Act no. 60 of 1960, § 2(e).

17 Sheela Barse v. Union of India, 1986 SCALE (2) 230. 


\begin{abstract}
"we would suggest that instead of each state having its own children acts different in procedures and content from those in other states, it would be desirable if the central government initiates the Parliamentary legislation on the subject so that there is complete uniformity in regard to the various provisions relating to children in the entire territory of the country."
\end{abstract}

Subsequently, the Parliament enacted the Juvenile Justice Act, 1986. However, there was a wide gap between the cherished principles and the actual practices under the JJ Act, 1986. Therefore, the Parliament enacted the Juvenile Justice (Care \& Protection) Act, 2000. The new legislation, Juvenile Justice Act, 2015 has introduced a new provision enabling the transfer of children aged between 1618 years to children's court, in cases where in a heinous offence is alleged to have been committed by a child.

\title{
3. International Covenants on Juvenile Justice
}

The JJ Act, 2015 fails to conform to the International charters on Human Rights, which are invoked in its preamble.18The Declaration of the Rights of the Child, commonly known as "Declaration of Geneva", the first international instrument on children's rights, advocated that child offenders should be transformed, not penalized. ${ }^{19}$ The instrument casts a duty on humankind that "the delinquent child must be reclaimed". The United Nations Standard Minimum Rules for the Administration of Juvenile Justice, also known as Beijing Rules, categorically spelt out the minimum standard to be followed by member states. It states in detail, the treatment to be meted out to juveniles without distinction of any kind. ${ }^{20}$ It focuses on rehabilitation aspects of the juvenile, ${ }^{21}$ while also stipulating a variety of dispositions. ${ }^{22}$

18 The Juvenile Justice (Care and Protection of Children) Act, 2015, No. 02 of 2016, India Code, Preamble (2015).

${ }^{19}$ Covenant of the League of Nations adopting Geneva Declaration of the Rights of the Child on 26 September, 1924.

20 G.A. Res. 40/33, United Nations Standard Minimum Rules for the Administration of Juvenile Justice (Nov. 29, 1985).

${ }^{21} I d$. Rules 24.1 and 25.1. 
The United Nations General Assembly (hereinafter referred to as the UNGA) adopted two significant instruments in 1990. The UN Guidelines for the Prevention of Juvenile Delinquency (the Riyadh Guidelines) stressed and recognized in spirit that:

"part of maturing often includes behavior that does not conform to societal norms and that tends to disappear in most individuals with the transition to adulthood and avoid labelling a youth a deviant or delinquent as this contributes to negative patterns of behavior". 23

The UN Rules for the Protection of Juveniles Deprived of their Liberty (the Havana Rules)is the first international instrument that defines a juvenile in terms of age. It recognizes that a juvenile is every person under the age of $18 .{ }^{24}$ The Convention on the Rights of the Child (hereinafter referred to as CRC), 1989 is an international treaty which India has signed as well as ratified. It emphasizes on inter alia, best interests of the child and social reintegration. ${ }^{25}$ The reduction of age from 18 to 16 years and transfer of a child onto the criminal justice system, is a failure on the part of India to observe International conventions. It goes against the spirit of the CRC and basic human rights, thereby violating international standards, which, paradoxically, find mention in the preamble to the JJ Act, 2015.26

\section{Injustices under Section 15}

The most crucial change brought about by the JJ Act, 2015 is that, under Section 15 of the JJ Act, 2015, a child who has completed or is above the age of 16 years can potentially be tried as an adult. Under the Act, a child has been defined as a person who has not attained

22 Id. Rule 18.

23 G.A Res. 45/112, United Nations Guidelines for the Prevention of Juvenile Delinquency (Dec. 14, 1990).

24 G.A Res. 45/113, United Nations Rules for the Protection of Juveniles Deprived of their Liberty (Dec. 14, 1990), Rule 11(a).

25 G.A Res. 44/25, Convention on the Rights of the Child (Nov. 20, 1989).

26 The Juvenile Justice (Care and Protection of Children) Act, 2015, No. 02 of 2016, India Code, Preamble (2015). 
18 years of age. ${ }^{27}$ Therefore, there is no change in the definition of the child per se. Although the Act has not reduced the age in the definition, Section 15 of the Act has reduced the age of a child from 18 to 16 years for the purpose of treating a child as an adult for heinous offences, thus proving to be a glaring and unavoidable inconsistency.

Section 15 of the JJ Act, 2015 mandates the JJB to conduct a preliminary assessment of children to understand their mental status. The JJB may take the help of psycho-social workers, psychologists and other experts to ascertain their mental capacity. If the Board is satisfied that the child possesses the mental capacity to commit such a crime on the basis of the preliminary assessment conducted therein, it may send the child to be tried as an adult by Children's Court under Section 18(3). This change is relevant, as such a transfer entails a protracted process, characterized by an extremely adversarial hearing. ${ }^{28}$ The Children's court, in turn, uses Blended sentencing, known also as extended jurisdiction juvenile (hereinafter referred to as EJJ), in which the courts can try the juvenile either as a child or as an adult. Further, the child is given a juvenile sentence to be served at a place of safety, until he becomes a major, after which he is transferred to an adult prison. ${ }^{29}$ The blended sentencing rendered by the courts is more punitive in nature as it allows children to be sentenced as an adult. This convergence eventually erodes the rationale for a separate juvenile justice system. ${ }^{30}$ It is beyond comprehension and somehow paradoxical as well, that the same courts established for the protection of the child's dignity is now violating it. ${ }^{31}$ The Apex Court has time and again held that the dignity of a child is of

27 The Juvenile Justice (Care and Protection of Children) Act, 2015, No. 02 of 2016, India Code, §§ 2(12), (13) (2015).

28 The Juvenile Justice (Care and Protection of Children) Act, 2015, No. 02 of 2016, India Code , § 15 (2015).

29 The Juvenile Justice (Care and Protection of Children) Act, 2015, No. 02 of 2016, INDIA CODE,\$19(3).

30 M. Tonry \& M. H. Moore, Youth violence, 24 Chi. Uni. of Chicago Pres. 189-261 (1998).

31 The Juvenile Justice (Care and Protection of Children) Act, 2015, No. 02 of 2016, INDIA CODE, § 2(20); Manjula Krippendorf v. State (Govt. of NCT of Delhi) and Ors, AIR 2017 SC 3457. 
extreme significance and emphasizes on the sustenance of such dignity. ${ }^{32}$

The United Nations Convention on the Rights of the Child (hereinafter referred to as UNCRC), and the Beijing Rules advocated that child offenders should be dealt with differently from adult offenders. General Comment No.10 specifically reminds State Parties of their obligations under the CRC:

"they have recognized the right of every child alleged as, accused of, or recognized as having infringed the penal law to be treated in accordance with the provisions of article 40 of CRC. This means that every person under the age of 18 years, at the time of the alleged commission of an offence, must be treated in accordance with the rules of juvenile justice". 33

These conventions and Charters provide a separate treatment for youthful offenders through what can be termed as social defense. ${ }^{34}$ India was one of the member states and in the year 1992, it had ratified the $C R C$, the world's most heavily ratified human rights treaty. ${ }^{35}$ Despite ratifying it, the Government has overturned this well-entrenched practice of treating juvenile offenders different from adult offenders. It now allows the JJB's discretion to exclude children above 16 years of age, who have allegedly committed heinous offences from the benefit of a benevolent juvenile system.

Professor Chris Cunneen, ${ }^{36}$ a leading criminologist, has propounded the Labelling Theory. It postulates that juvenile

32 Tulshidas Kanolkar v. State of Goa, (2003) 8 SCC 590; Suchita Srivastava and Anr. v. Chandigarh Administration, (2009) 9 SCC 1; Reena Banerjee and Anr. v. Govt. (NCT of Delhi) and Ors., (2015) 11 SCC 725; Mofil Khan and Anr. v. State of Jharkhand, (2015) 1 SCC 67.

33 General Comment No. 10, Children's Rights in Juvenile Justice, para 37, 38 (2007)

34 K. Padmaja, Juvenile Delinquency, ICFAI University Press (2007)

35 Somalia and US Should Ratify UN Child Rights Treaty, Official. https://news.un.org/en/story/2010/10/355732-somalia-and-usshould-ratify-un-child-rights-treaty-official

36 Chris Cunneen, Juvenile Justice - An Austalian Perspective, Oxford University Press,28-90 (1995). 
delinquency is to be seen as a product of the juvenile's interaction with the criminal justice system, as it is responsible for shaping his behavior to a great extent. Once a juvenile commits a crime and is apprehended by the law enforcement agencies, his treatment as an adult in an adversarial criminal justice system such as that of India, contributes to his identity as a criminal. This identity is soon accepted by and attributed to the offender by both, the society as well as the justice system. The societal reaction manifesting in child labeling contributes to the child becoming a criminal. ${ }^{37} \mathrm{~A}$ general understanding is that a child is prone to take after the labels attributed to him. Consequently, if a child is called bad, that is the way the child will identify himself and consequently behave in the future. ${ }^{38}$ The very objective of the Act could have been to preclude the interaction of the juvenile with the interface of the adult justice system, as labeling of the juvenile contributes to negative patterns of behavior. The objective of treating a child as an adult under Section 15 is based on the retributive conception of punishment, which holds that the best response to a crime is a punishment proportional to the offense inflicted by the offender.

The Apex Court, in Subramanian Swami v. Raju, through the Juvenile Justice Board, provided cogent reasons while dismissing the petition against reducing the cut-off age from 18 to 16 years. ${ }^{39}$ In the case of Salil Bali v. Union of India, 40 the constitutionality of definition of child under 18 years was challenged as ultra vires Constitution. The Court held as follows.

"The age of eighteen years has been fixed on account of the understanding of the experts in child psychology and behavior patterns that till such an age the children in conflict with law could still be redeemed and restored to mainstream society, instead of becoming hardened criminals in future. It is probably better to try and reintegrate children with criminal propensities into

37 Justin Ashenfelter, Coming Clean: The Erosion of Juvenile Miranda Rights in New York State, 54 NY Lar Rev.(2012).

38 Richard D. Schwartz \& Jerome H. Skolnick, Two Studies of Legal Stigma, 10 Oxford Journal (1962).

39 Subramanian Swamy v. Raju, (2014) 8 SCC 390.

40 Salil Bali v Union of India, (2013) 7 SCC 705 
mainstream society, rather than to allow them to develop into hardened criminals, which does not augur well for the future." 41

The Juvenile Justice (Care and Protection) Bill, 2014 was examined by the Department Related Parliamentary Standing Committee, which in its $264^{\text {th }}$ report took note of the concerns raised by stakeholders, with regard to certain provisions of the legislation being ultra vires of the Constitution. The Committee also took cognizance of the fact that the most vulnerable section of the society, the children, are likely to be adversely affected by the legislation. 42 It rejected the bill as being unwarranted and unconstitutional in the following words: 43

"[T]he existing Juvenile Justice Act, 2000 is not only reformative and rehabilitative in nature but also recognizes the fact that 16-18 years is an extremely sensitive and critical age requiring greater protection. Hence, there is no need to subject them to a different or an adult judicial system as it will violate Article 14 and 15(3) of the Constitution. We also took notice of the Crime in India, 2013 by the National Crimes Records Bureau which shows juvenile crimes to be 1.2 percent of the total crimes committed. It is evident that juvenile crime is not significantly increasing so as to warrant bringing radical changes in the legislation, which could very well be tackled within the existing framework, with appropriate infrastructure".

The Justice Jagdish Sharan Verma Committee constituted in the aftermath of the 2013 Delhi gang-rape case, to look into possible amendments to criminal law, also recommended against the reduction of the age of the juvenile.44 Despite cogent reasons proposed by the committees and the Apex Court, the parliament

41 Salil Bali v Union of India, (2013) 7 SCC 705

42 Two Hundred Sixty Fourth Report The Juvenile Justice (Care and Protection of Children) Bill, 2014, Parliament of India, http:// www.prsindia.org/ uploads/media/ Juvenile\%20Justice/ SC\%20 report-\%20Juvenile\%20justice.pdf.

43 Id at para 3.21, Pg. 30.

44 Report of the Committee on Amendments to Criminal Law, Gov. of India, https:/ / searchworks.stanford.edu/view/10772631. 
succumbed to popular demand resonating through media frenzy and proceeded with the Act in its present form.

\subsection{Ambiguous Classification in the Legislation}

The JJ Act, 2015 has introduced a three-fold classification of offences as petty, serious, and heinous offences. Such a classification is ridiculous, not only with respect to JJS but also with regard to the criminal justice system..$^{45}$ Apart from the difference in the treatment of a child, the classification serves to determine the "crime de jour" for which a child above 16 years and below 18 years can potentially be tried as an adult. ${ }^{46}$ Therefore, it is very important to understand the classification made under the act as differential treatment of a child is based particularly on this classification.

Petty offences are those offences for which the maximum punishment under the Indian Penal Code, or any other law, is imprisonment up to three years. ${ }^{47}$ For serious offences the punishment is imprisonment between three to seven years. ${ }^{48}$ Heinous offences include offences for which the minimum punishment under the Indian Penal Code or any other law is imprisonment for seven years or more. The definition of petty offences does not pose any difficulty, as it includes only those offences that are punishable with imprisonment for a period not exceeding three years. However, the definitions of both serious and heinous offences are vaguely worded. There are several offences which fall within this ambiguous zone - where the maximum punishment is more than seven years and no minimum punishment has been mentioned or where the minimum punishment is less than seven years. Neither do such offences fall

45 Ved Kumari, Juvenile Justice Act, 2015-Critical Understanding, Indian L. Inst. (2017).

46 Handbook for Advocates working with Children in Conflict with Law in India, Nat'l Law School of India University, https:// www.nls.ac.in/ ccl/ publications/handbook.pdf.

47 The Juvenile Justice (Care and Protection of Children) Act, 2015, No. 02 of 2016, India Code, § 2(45) (2015).

48 The Juvenile Justice (Care and Protection of Children) Act, 2015, No. 02 of 2016, India Code, § 2(54) (2015). 
within the ambit of heinous nor serious offences. They also do not fall within the category of petty offences.

The definition of heinous offences leaves out a considerable number of offences. For example, Section 304 of the Indian Penal Code, lays out the punishment for culpable homicide not amounting to murder. It is prescribed that the punishment may extend to ten years. As only the maximum period of imprisonment, and no minimum period is mentioned under Section 304, the offence will not fall within the category of heinous offence. Another such example is the offence of robbery which is punishable with imprisonment for a term which may extend to ten years... and, if the robbery is committed on the highway between sunset and sunrise, the imprisonment may be extended to fourteen years. Therefore, such offences which are punishable with imprisonment not exceeding ten years as in Section 392, (or any other term exceeding seven years,) cannot be classified into any category of offences envisaged by the JJ Act, 2015. There is ambiguity as to whether such offences are to be treated as serious offences (as the minimum punishment rendered may or may not be between 3 to 7 years) or are they to be treated as heinous offences (as no such minimum punishment is mentioned under such sections)? There are at least 55 offences under the IPC, which do not fall under the definition of serious or heinous offences. The description of the stipulated category of offences has created unwanted confusion as many offences under the Penal Code do not fall within these definitions. The adversities are graver if, due to this ambiguity, a case is treated to be heinous. In such a case, the child may be deprived of the protection of the juvenile justice system. There are several offences which fall within this ambiguous zone.

\section{Psychology and Juvenile Delinquency}

Section 15 of the JJ Act, 2015 places an onerous obligation on the Board to assess the mental and physical capacity of the child, specifically when such a child is above the age of sixteen. In pursuance of this, the Board may take the assistance of experienced psycho-social workers, psychologists or other experts for assessing the child's mental and physical capacity to commit the crime. However, the Act has failed in establishing a universally accepted 
definition, leaving room for ambiguity and consequently, arbitrariness. Psychological sciences cannot adequately deconstruct this concept in a manner that allows for an accurate and reliable assessment. Neither can psychology nor human development sciences, precisely identify the chronological age at which such capacity exists in its entirety. ${ }^{49}$ The question of where to draw the line between a child and an adult is subjective, and is ultimately arbitrary. ${ }^{50}$ In the case of $S v D y k,{ }^{51}$ Justice Corbett argued that the danger inherent in applying a vague, generalized right and wrong test is that, in an instance like this, such a child could well be found criminally responsible. Research on the relevance of neurodevelopment milestones, in determining the minimum age of criminal responsibility has been brought to the fore ${ }^{52}$ over the last 15-20 years. Modern technological advances, particularly in medical imaging technology, have concluded that adolescent brains are not as fully developed as adults until age 25.53 In Stanford $v$. Kentucky, ${ }^{54}$ the US Supreme Court observed that "children, those under the age of 18 but even as old as 16 and 17, are not sufficiently able to control their impulses, nor to fully understand the consequences of their risky behavior." In a 2005 case, Roper $v$. Simmons, 55 achild of 17 years was sentenced to death penalty. In an attempt to reverse the judgment, the American Psychological Association submitted amicus briefs to the Supreme Court of the United States, to exhibit that at the age of 17 years, the adolescent brain is still developing. Based on the scientific evidence supporting the amicus brief, the Supreme Court countermanded the

${ }^{49}$ Anthony L Pillay \& Clive Willows, Assessing the Criminal Capacity of Children: a Challenge to the Capacity of Mental Health Professionals, 27 Journal of Child and Adolescent Mental Health 91-101 (2015).

50 Robert O. Dawson, The Future of Juvenile Justice: Is It Time to Abolish the System?, 81 The Journal of Cri. Law and Criminology 136-155 (1990)

${ }^{51}$ S v Dyk, (1969(1) SA 601(C)

52 Michael E Lamb \& Megam PY Sim, Developmental Factors Affecting Children in Legal Contexts, 13 Sage Journals 131-144 (2013).

${ }^{53}$ Supra note 7.

54 Stanford v. Kentucky, 492 US 361.

55 Roper v. Simmons, 543 US 551 (2005); Graham v. Florida, 560 US 48 (2010); Miller v. Alabama,567 US 460 (2012). 
death penalty. ${ }^{56}$ It is suggested that the JJBs send the child for preliminary assessment to psychiatric departments of state-run hospitals, for ascertaining the mental health of the child. Owing to infrastructural and financial deficits which plague these hospitals, it can reasonably be concluded that such departments may not be suitable to assess the requisite criteria. A psychologist is unable to satisfy the requirement under Section 15(1) of JJ Act, 2015 as they are skilled to identify mental illness/disorders, and not the 'mental or physical capacity' of the child, which even psychiatric/psychosocial workers cannot do. ${ }^{57}$ The process of assessment of a child, especially in this setting, is a complex task, time consuming and costly to be applied to each child.58 The JJ Act, 2015 is willfully blind to neuro developmental sciences, social sciences, and foundational religious teachings about human nature. It is unfortunate that in spite of abundance of research in this field, the legislature, riding on the emotions of erroneous public opinion brought into effect the JJ Act, 2015.

\section{Juvenile Justice and the Constitution}

The Preamble of the JJ Act, 2015 refers to Articles 15(3), 39(e) and (f), 45 and 47 of the Constitution. It states that such Articles cast an obligation "on the State to ensure that all the needs of children are met and that their basic human rights are protected".59 The transfer system of a child to adult criminal system under the Act, violates the right to equality under the Constitution. Article 14 prescribes equality before law, but the fact remains that all are not equal by nature, circumstances, attainment, and hence a mechanical equality before the law results in injustice.60 The Supreme Court has underlined this principle thus:

56 Aliya Haider, Roper v. Simmons: The Role of the Science Brief 369-377, 3 Ohio State Journal of Criminal Law (2006).

57 K. M. Banham Bridges, Factors Contributing to Juvenile Delinquency, 17 Journal of Crim. L. \& Criminology (1927).

58 Budget for Children in New India, Center for Child Rights, http:// haqcrc.org/wp-content/uploads/2018/02/haq-budget-for-children2018-19.pdf.

59 R.D Upadhyay v. State of A.P and Ors., AIR 2006 SC 1946.

60 M.P Jain, Indian Constitutional Law 907-09 Lexis Nexis (2018) 


\begin{abstract}
"Article 14 of the Constitution ensures equality among equals: its aim is to protect persons similarly placed against discrimination. It means that equals should be treated alike; it does not mean that 'unequals ought to be treated equally'. Persons who are in the like circumstances should be treated equally. On the other hand, where persons or groups of persons are not situated equally, to treat them as equals would itself be violative of Article 14 as this would result in inequality". 61
\end{abstract}

Children and adults being on an unequal footing with respect to their psychological development, ought not to be treated alike. Subjecting children to the same criminal justice system as adults, is premised on the flawed assumption that children and adults can be held to the same standard of culpability and that children are capable of participating in legal proceedings in a like manner. ${ }^{62}$ When one expects the same level of psychological understanding and behavior as adults from children, one is guilty of treating unequals as equals and as a consequence, violating Article 14. The most important way in which a child is different from an adult is that he/she is in the process of becoming an adult - a state that has been described as semiautonomous. ${ }^{63}$ Therefore, holding them to the same standards of culpability as adults, is not appropriate. Further Article 15(3) of the Constitution mandates that states make special provisions in favor of children, not against them. ${ }^{64}$ The state has a Constitutional obligation to safeguard their interests and welfare in the real sense, not by doing them a favor, as charity. ${ }^{65}$

\footnotetext{
61 RK Garg v Union Of India, AIR 1981 SC 2138.

62 Supra note 49.

63 Franklin E. Zimring, The Changing Legal World of Adolescene, MAcmillan Publishing Co. New York, (1985)

64 Sri Mahadeb Jiew and Anr. v. Dr. B.B Sen, AIR 1951 Cal 563; Independent Thought v. Union of India, AIR 2017 SC 4904.

65 Sampurna Behura v. Union of India (UOI) and Ors., (2018) 4 SCC 433.
} 


\section{Avenues for Change: Possible Solutions}

'Hard Cases make bad law,' is an old adage which dates back to 1837. It was an observation made by Justice Robert Rolf in the case of Winterbottom $v$ Wright in 1842:

"This is one of those unfortunate cases...in which, it is, no doubt, a hardship upon the plaintiff to be without a remedy but by that consideration we ought not to be influenced. Hard cases, it has frequently been observed, are apt to introduce bad law".66

The observation made by Judge Robert Rolf, has sound implications. Laws should be made for the benefit of the general population. The laws enacted should reflect average circumstances and should not be based on extreme cases, as they form a poor basis for the enactment of laws. The Nirbhaya case, where a medical student was brutally gang raped is one such bad example. The juvenile offender who prompted the nation-wide debate about the effectiveness (or lack thereof) of the JJ Act, was termed as the most brutal amongst all offenders. India has taken a step-backward by introducing JJ Act, 2015 on the basis of one bad case of involving a barbaric gang-rape in which one of the juvenile offenders was just a few months short of attaining majority.

The government also jettisoned its responsibility to take into account the experience of countries which have adopted the practice of transfer of children to the adult criminal justice system. These countries have had higher rates of recidivism. ${ }^{67}$ The Court in Madrid v. Gomez, ${ }^{68}$ observed that the modern prison life may press the outer bounds of what most humans can psychologically tolerate. In the words of Krishna Iyer, J, adult prisons are like

66 Winterbottom v Wright, 152 ER 402.

67 Donna Bishop et. al., The Transfer of Juvenile to Criminal Court: Does it make a difference?, 42 Crime and Delinquency, 171-91 (1996); Karen Miner-Romanoff, Juvenile Offenders tried as adult: What they know and implications for practitioners, 41 Northern Kentucky L. Rev. 205-224 (2014); Deanie C. Allen, Trying Children as Adults, 6 Jones L. Rev. 27-64 (2002).

68 Madrid v. Gomez, 889 F. Supp. 1146 (ND Cal. 1995). 
"animal farms".69 The future of child offenders in adult prisons, presents a bleak picture. Owing to such a system, the juveniles are at a greater risk of committing suicide and suffering from sexual and physical abuse meted out to them by older inmates. A direct causal link can be drawn to the effects of the brutalization and the harms suffered by juveniles. ${ }^{70}$ The culture and environment in prison, fosters behavior in juveniles that increases their chance of recidivism. They are also exposed to techniques which they can utilize, in order to indulge in illegal activities, on their return to the society. ${ }^{71}$ The author suggests that rehabilitation plays a very crucial role in the Juvenile justice system. Rehabilitating a juvenile, who has committed an offence, itself can have a deterrent value, because successful rehabilitation results in specific deterrence.

\section{A Comparative Analysis of Juvenile Justice Systems}

The problem of juvenile delinquency is not confined to a particular country. It is a global phenomenon. However, the age at which a person is considered a juvenile, differs significantly from country to country, and so do the approaches to tackle juvenile delinquency. ${ }^{72}$ In this section, the author will examine how other countries in different parts of the world are addressing juvenile delinquency.

\subsection{Uganda's Juvenile Justice System}

Uganda ratified the UNCRC in 1990. In 1996, Uganda enacted its own juvenile legislation. The legislation reflects the commitment of Uganda, a developing country with scant resources, to import children's rights into local laws, as enshrined in the CRC. This is evident in the measures taken by the Ugandan government to place its law in conformity with the CRC, delivering of justice to children, strengthening child protection structures and helping to build a

69 Satto v. State of UP, (1979) 2 SCC 628.

70 William C. Bailey, Deterrence, brutalization, and the death penalty: Another examination of Oklahoma's return to capital punishment, 36 Criminology 711-33 (1998).

71 Richard E. Redding, Adult punishment for Juvenile offenders: Does it reduce crime? 47 (Illanova Uni. School of Law Working Paper Series. 1-37 (2006).

72 Supra note 38. 
protective environment for children. ${ }^{73}$ Uganda has adopted a childcentric approach in its Constitution. Article 34(6) of the Constitution of Uganda provides for separate treatment of child offenders and further entailed that a child offender shall not be detained with adults.74 The commitment to put into effect the Constitutional provision on children, is reflected in Section 4 of the Children's Act which gives the welfare of the child top-most priority. ${ }^{75}$ The maximum punishment which a Family and Children court (FCC) can inflict cannot be more than three years in case of an offence punishable by death and three months in case of any other offence. ${ }^{76}$ Uganda carried out an amendment in its Children's Act in 2016. As per the new amended Act, the country has also specifically focused on the core issues which lead to the juvenile offences. Section 6 of the Act emphasizes on parental responsibility to provide basic amenities such as education, immunization, diet, clothing, and medical attention and so on. ${ }^{77}$ The principle of diversion has been paid much attention by Uganda, where a child alleged to have committed a crime is let off at the time of apprehension, with a mere warning, without resorting to formal court proceedings. ${ }^{78}$ In the Republic of Uganda v. O.D (a juvenile), ${ }^{79}$ the High Court of Uganda held that the statute conceives the detention of a child as a serious measure, which must be resorted to only as a last resort. It must be reserved for the worst cases. ${ }^{80}$

\subsection{The South African Perspective}

The South African Republic ratified the CRC in 1995. After having ratified the $\mathrm{CRC}$, it has adopted a sustainable juvenile legislation after much contemplation. The South African juvenile system has been crafted in a manner that the majority of children will be dealt with outside the criminal justice system, without recourse to the

73 Uganda v. Bedayika Nancy 19 (2016).

74 Uganda Const. Art. 34.

75 Children Act, Act. no. 6 of 1996, Chap. 59 (1997).

76 Atandu Marcelo v. Uganda (COA) (2009) 0009.

77 Children Act, Act. no. 6 of 1996, Chap. 59 (1997) § 6.

78 Children Act, Act. no. 6 of 1996, Chap. 59 (1997). §§ 89 (1), 89(2), 89(6).

79 The Republic of Uganda v. O.D (a juvenile) (2018) UGHCCRD 159.

80 The Republic of Uganda v. O.R (Juvenile) (2018) UGHCCRD 156; Uganda v C.B. (a juvenile) (2018) UGHCCRD 163. 
formal court system. Section 28(2) of the Constitution of South Africa gives due regard to the best interests of the child, when dealing with matters involving them. It also enumerates the right of the child to be kept separately from adult offenders. ${ }^{81}$ The Child Justice Act passed in 2008, in pursuance to the constitutional mandate, promotes the ethos of $u b u n t u,{ }^{82}$ (the concept of common humanity)thus preventing children from being tried in the adversarial court system. This is achieved by resorting to mechanisms which are more suitable to the interest of the child and in accordance with the Constitution of South Africa, including the use of diversion. ${ }^{83}$ In Director of Public Prosecutions, Transvaal $v$. Minister of Justice and Constitutional Development and Ors. ${ }^{84}$ the Constitutional Court of South Africa held that "Courts are bound to give effect to the provision of Section 28(2) in matters which involve children and are obliged to give consideration to the rights and best interests of the child."

\subsection{Juvenile Justice in France}

The French Juvenile system resorts to educative solutions, rather than to impose punitive measures. This has been France's choice for over 60 years, since the Order of 2 February 1945.85 Article 8 of the Order, reflects the desire of the society to ensure the best possible future for its children, by reintegrating them into the community, by dealing with the core issues such as the moral status of their

81 South Africa Const. § 28 (1) (g), (2); Centre for Child Law v Minister of Justice and Constitutional Development 2009 2 SACR 477 (CC) para 29; Centre for Child Law v Minister for Justice and Constitutional Development 20096 SA 632 (CC) para 14(d).

82 Nkem Ifejika, What does ubuntu really mean?, THE GUARDIAN (Sept. 29, 2006,), https://www.theguardian.com/ theguardian/ 2006/ sep/ 29/ features11.g2

83 S v. M (2007) 2 SACR 539 (CC); Child Justice Act, 2008, Act. no. 75 of 2008, § 2 (2008); South Africa Const. art.28.

84 Director of Public Prosecutions, Transvaal v. Minister of Justice and Constitutional Development and Ors., (2009) 4 SA 222 (CC).

85 Catherine Blatier, Juvenile Justice In France: The Evolution of Sentencing for Children and Minor Delinquents, 39 The British Journal of Criminology Oxford University 240-252 (1999); GATON STEFANI ET AL., DROIT PÉNAL GÉNÉRAL ET PROCÉDURE PÉNALE (17th ed. 2000). 
family, the educative environment, the conditions in which they have been brought up, rather than relying on preventive measures to ensure their rights. ${ }^{86}$ France does not have the same system of transferring juveniles to adult criminal courts as India. In an interview with Judge Catherine Samet, Investigative Judge, Tribunal de Grand Instance, in Nanterre Prefecture (suburb of Paris), the Judge emphasized on the Humanist approach towards Juvenile offenders as the cornerstone of the French Juvenile Justice System. ${ }^{87}$ The whole programme is aimed at educating juveniles as an alternative to imprisonment. This helps in preventing delinquency in its nascent stage itself, at the school and family level. Consequently, positive results are visible in France.

\section{Ideas India can Adopt}

An analysis of how other countries are tackling juvenile delinquency with a child-centric approach, offers valuable lessons for India. First, without exception, in all the countries reviewed herein, there is a tendency to tackle the core issues which lead to juvenile delinquency such as moral status of family, child's education et cetera to prevent delinquency at its nascent stage. Second, juvenile legislations in all the aforementioned countries have been balanced in such a way, so as to secure the best interests of the child, without taking recourse to the formal legal system. The principle of diversion has also been paid much attention. Third, fundamental to all these countries is the separate treatment of a child in a system distinct from the adult criminal justice system. The lesson for India is that Criminal conduct and its influence on society depends on the treatment juveniles receive today. 88 Preventing today's juvenile offenders from engaging in future

86 Anne Wyvekens, The French Juvenile Justice System, Int'1 Handbook of Juvenile Justice, Springer 173-186 (2006).

87 Calvin Peeler, Always a Victim and Never a Criminal: Juvenile Delinquency in France, 22(3) N.C.J. INT'L L. \& COM. REG. 886-87 (1997).

88 Del Carlo Shari, Oregon Voters Get Tough on Juvenile Crime: One Strike and You are Out!, 75 OREGON L. REV. 1224-40 (1996). 
criminal activity is a more realistic and humane goal than forfeiting the future of an entire segment of the population. ${ }^{89}$

\section{Conclusion}

The JJ Act, 2015, by introducing the provision of transfer has taken a step backward, while defeating the sui generis status of a child. The object of the JJ Act, 2015, as it presently stands, leans more towards managing juvenile offenders than rehabilitating them. The committee examining the Juvenile Justice bill, 2014 was appraised by the Ministry of Women and Child Development, regarding the various problems in the existing JJ Act, 2000. These problems ranged from a delay in inquiries, lack of clarity pertaining to roles, functions, responsibilities, accountability of JJBs and also reports repeated instances of abuse of children in the institution. Instead of strengthening the Act of 2000, which was more appreciative of the developmental needs of the child, the government rushed to enact a whole new piece of legislation, which is a retrograde step likely to serve no purpose..$^{90}$ It is also found that children below the age of 18 are not likely to exhibit sufficient competence in either juvenile or criminal courts. Several instances of a child being a defendant in an adversarial court proceeding, hampers the chance of securing justice, as juveniles are less likely to communicate effectively and trust their lawyers, both being indispensable in establishing a legal defense. It has changed the approach of law towards children in the direction of a law-driven system and away from treatment-driven system. The government has passed the JJ Act, 2015, bypassing the core issues pertaining to the rights of the child. The steps undertaken by the government for the welfare of the child has paid less attention to the core issues which lead to juvenile delinquency.

89 Jeffrey K. Day, Comment, Juvenile Justice in Washington: A Punitive System in Need of Rehabilitation, 16 U. Puget SOUND L. ReV. 399, 443 \& n.311 (1992); Martin L. Forest \& Martha-Elin Blomquist, Cracking Down on Juveniles: The Changing Ideology of Youth Corrections, 5 NOTRE DAME J.L. ETHICS \& PUB. POL'Y 323, 443 (1991).

90 Supra note 45, para 1.4, Pg.9. 
As it has already been observed, criminal behavior is caused by unwholesome environmental determinism of a child. ${ }^{91}$ The current emphasis of the law should shift "from assessing the social harm that the offender has done to assessing the social needs of the offender. According to Locke, education is the only way to "[set] the mind right " and help in finding a solution for juvenile delinquency ${ }^{92}$ Creating a system that focuses on early intervention is extremely important. The focus should lie in strengthening the institutions of education and family. These can be expensive, but much economical if the bigger picture is taken into account. Taking steps in this regard will most likely be practically useful to invest in the child's overall development, rather than labelling them as unredeemable.

As the law has already been passed, the author suggests that trying juveniles as adults should be rare and applied for only the most severe, violent crimes. Model rules should be enacted to try a juvenile as an adult, only in the rarest of the rare cases. Adult prisons do not encourage positive change in offenders nor does it focus on rehabilitation aspects. Instead, it creates an environment that encourages further criminal activity. The affirmative steps the system must take to rehabilitate the offender must necessarily focus on not causing more harm. This would facilitate the child into becoming a law-abiding citizen.

91 Court on Its Own Motion v. Dept. of Women and Child, WP (C) No. 8889 of 2012.

92 Ruth W. Grant and Nathan Tarcov, John Locke, Some Thoughts Concerning Education, 49, Hackett Publishing Company, Inc. (1996) 